\title{
Empleo de la vena femoral para la canalización de un catéter venoso central permanente tunelizado para hemodiálisis
}

\author{
Raquel Pelayo Alonso, José Luis Cobo Sánchez, Soraya Sánchez Cano, Marina Rojo Tordable, Alicia Tovar \\ Rincón, Magdalena Gándara Revuelta
}

Hospital Universitario Marqués de Valdecilla. Cantanbria

\section{Introducción:}

Según la guía de acceso vascular (AV) para Hemodiálisis de la SEN, la fístula arteriovenosa interna (FAVI) debe ser la primera opción de $\mathrm{AV}^{1}$. Sin embargo, no siempre es posible disponer de un AV autólogo², por lo que los catéteres venosos centrales (CVC) se han convertido en una alternativa cada vez más frecuente ${ }^{3}$. No obstante, en ocasiones se debe recurrir a localizaciones anatómicas no tan recomendadas, por su alta tasa de complicaciones, como puede ser el caso de la vena femoral ${ }^{4}$. Presentamos un caso clínico de un paciente portador de un CVC tunelizado, insertado en la vena femoral izquierda. Descripción del caso: Varón de 67 años, diagnosticado de nefroangioesclerosis en tratamiento renal sustitutivo (TRS) desde abril de 1992. Antecedentes personales: Hipertensión arterial, hiperlipidemia, hiperuricemia, hipercoagulabilidad por déficit de factor $\mathrm{V}$ de Leiden en tratamiento con heparina de bajo peso molecular, shock hipovolémico secundario a desgarro vascular de vena yugular interna derecha, trombosis yugulo-subclavial bilateral. Antecedentes del TRS:

- 3 trasplantes renales fallidos, con una duración total de 4 años.

- Diálisis peritoneal durante 2 años precisando salir de programa por infecciones de repetición.

- 3 FAVIs en distintas localizaciones, ninguna de ellas funcionante.

- FAVI con injerto autólogo de safena fallida.

- 12 catéteres venosos centrales en diversas localizaciones retirados por bacteriemia o trombosis.

En la actualidad, el paciente es portador de un CVC tipo Palindrome ${ }^{\circledR}$ insertado en vena femoral izquierda. El catéter inmediatamente anterior al actual se trataba de un catéter tipo Tessio insertado en femoral izquierda. Se retiró tras 3 años, precisando recambios de ramales por obstrucción. El sellado se realizaba con heparina al $5 \%$ y se desobstruyó en varias ocasiones con uroquinasa según protocolo de nuestro centro. Finalmente se trombosó, adhiriéndose a la pared del vaso. Durante el proceso de retirada e inserción del nuevo catéter, se precisó dilatación del eje iliaco con balón de angioplastia de 7 $\mathrm{mm}$, colocándose el nuevo catéter hasta vena cava inferior. Actualmente, el paciente se dializa tres veces por semana, con una duración de 240 minutos por sesión a un flujo de 300-350 ml/min y con una presión arterial y presión venosa media de $-220 \mathrm{~mm} \mathrm{Hg}$ y $150 \mathrm{~mm} \mathrm{Hg}$ respectivamente. Mantiene correctos parámetros analíticos con un $\mathrm{Kt} / \mathrm{V}$ de 1,4 y una tasa de recirculación del $5-7 \%$, realizando las sesiones sin complicaciones. Respecto a las complicaciones infecciosas, durante los 4 años que el paciente ha tenido insertado un CVC tunelizado en femoral sólo ha presentado una bacteriemia relacionada con el catéter y una infección del orificio de salida, sin precisar la retirada del mismo por estas complicaciones.

\section{Conclusiones:}

El uso de la vena femoral para la implantación de un CVC permanente para el tratamiento con hemodiálisis es una buena opción en pacientes donde su capital venoso está agotado. La vigilancia estrecha y un manejo adecuado por parte de enfermería han permitido que a pesar de las complicaciones infecciosas, que a priori pueden suponer el principal inconveniente de esta localización, el catéter sea viable, en un paciente con mínimas alternativas en cuanto a su AV. 


\section{Referencias Bibliográficas}

1. Rodríguez Hernández JA, González Parra E, Gutiérrez Julian JM, Segarra Medrano A, Almirante B, Martínez MT et al. Guías SEN. Guía de acceso vascular en hemodiálisis. Nefrología 2005; 25(Supl 1): 64-92.

2. Malek T, Álvarez-Ude F, Gil MT, Moledous A, López-Collado $M$, Núñez $C$ et al. Cambios en el acceso vascular en una unidad de diálisis en los últimos años: ¿problemas de planificación, cambios de preferencias o cambio demográfico? Nefrología 2008; 28(5):531-538.
3. Sociedad Española de Nefrología. Organización Nacional de Trasplantes. Registro Español de Enfermos Renales. Informe de diálisis y trasplante 2010. [Consultado 25 febrero 2013] Disponible en: http://www.senefro.org/modules.php?name $=$ w ebstructure\&idwebstructure $=128$.

4. Crehuet I, Mendinueta S, Méndez P, González R. Catéter translumbar en vena cava inferior: última opción de acceso vascular para hemodiálisis. Rev Soc Esp Enferm Nefrol 2008; 11 (3): 238/241. 